\title{
PRESENT STATUS ON THE USE OF ANABOLIC STEROIDS AND FEED ADDITIVES IN SMALL SCALE CATTLE FATTENING IN BANGLADESH
}

\author{
M. H. Islam, M. A. Hashem*, M. M. Hossain, M. S. Islam, M. S. Rana and \\ M. Habibullah \\ Department of Animal Science, Bangladesh Agricultural University \\ Mymensigh-2202, Bangladesh
}

\begin{abstract}
This study was conducted to find out the relationship among different aspects of cattle fattening and use of anabolic steroids and feed additives. The data were collected through an interview schedule from 150 respondents of 6 upazila of 3 districts who were involved in small scale cattle fattening. Parameters were studied in relation to socio-economic conditions of farmers and use of anabolic steroids and feed additives and their effects on animals and environment. In this study $72 \%$ farmers' were involved in agriculture, followed by $23.3 \%$ in livestock business. About $46 \%$ farmers had primary education, $10.7 \%$ had higher secondary school certificates, $5 \%$ obtained above higher secondary education and the rest of them were illiterate. Irrespective of literacy only $9.3 \%$ of the farmer had training. About $89.3 \%$ respondents used their own labors, $7.3 \%$ dependent on hired labor and the rest 3.3\% get labour from both sources. Results showed that about $58 \%$ respondents used anabolic steroids for the duration of 3 to 6 months long cattle fattening $(\mathrm{P}<0.001)$ program. The chi-square $(14.09)$ value of annual income indicates that with increase of annual income, use of anabolic steroids have decreased. The significant $(\mathrm{P}<0.01)$ association was observed in case of anabolic steroids and source of money, annual income, number of cattle fattening, breeds, fattening period, starting and finishing age. The $r_{s}$ value of annual income, source of money, starting and finishing age were positively correlated with feed additives. About $78 \%$ respondents used feed additives for cattle fattening from own resources $(\mathrm{P}<0.001)$ and most of cattle fattened for 3 to 6 months $(\mathrm{P}<0.01)$. The result demonstrated that respondents of low annual income used more anabolic steroid and feed additives as a growth promoter for cattle fattening and they prefer in powder form.
\end{abstract}

Key Words: Cattle fattening, Anabolic steroid, Feed additives, Farmers

\section{INTRODUCTION}

Cattle of Bangladesh are an inseparable and integral part of the agricultural farming and agribusiness system. About 24.5 million cattle heads are distributed throughout the

*Corresponding author:- E-mail: hashem_mdabul@yahoo.com, Mobile: 01721-310621 
country which ranks $12^{\text {th }}$ in the world and $3^{\text {rd }}$ in Asian countries (FAO, 2010). Although the growth of livestock production is the highest among all other sub-sectors of agriculture in Bangladesh (Bangladesh Economic Reviews, 2007), the production and consumption of livestock products is still much lower in comparison with other countries. Among meat consumption of 180 countries in the world, Bangladesh stands in 18 position which is about only $7.13 \mathrm{~kg} /$ capita/year (DLS, 2009) compared to the USA of $124 \mathrm{~kg}$ and the global average of $38 \mathrm{~kg}$ (Smith et al., 2007). The quantitative production of meat in Bangladesh in 2005 is 1.06 million tons against the total requirement of 6.30 million tons (BBS, 2009). The projected production of meat is 2.87 million tons in 2015, but its total requirement would be 6.86 million tons. It indicates a huge gap exit between production and the total requirement both in $2005(82.4 \%)$ and 2015 (58.2\%). Now a days cattle fattening has become an important business of the small farmers in Bangladesh. Cattle are bought by the farmers usually 3-6 months before Eid-ul-Azha (Muslim festival). According to Skunmun et al. (2002), the increasing trends of beef demand have already been evident in several Southeast Asian countries such as Indonesia, Malaysia, Philippines and Thailand. Good nutrition and management plays a key role behind cattle fattening (Hossain, 1986, Hossain et al., 1996 and Hashem et al., 1999). Growth stimulating substances like hormones, steroids, feed additives etc., are using in Bangladesh for cattle fattening. Hoffman et al. (2008) reported that antibiotics in sub-therapeutic dose are the safest and most effective with regard to human and animal health and associated bacterial resistance problems. They also reported that the antimicrobial agents that are used as feed additives develop their activity in the digestive tract.

In many countries, growth promoting steroids have been successfully used to increase the growth rate of animals, particularly in cattle. A scientific agreement was also adopted to prohibit the use of stilbenes owing to their potential tumor-inducing effects in human. However, most of these compounds have not gained widespread consumer acceptability and growth-promoting hormones were banned by the EU. The consequence of this EU position has been the development in numerous countries of a black market of hormone cocktails including potentially dangerous synthetic steroids and corticoids. The weight gain increase in steroid-treated animals was associated with net protein accretion and $\mathrm{N}$ retention without any changes in the digestibility of $\mathrm{N}$ intake (Scarth et al., 2009).

In Bangladesh, feed additives and growth promoters imported by pharmaceutical industries and overseas marketing agencies and attract farmers to use them in fattening animals. Some of them may have deleterious residual effects on human health or some may not respond cost effectively. Most of the cattle brought for sale as sacrificial animals in the northern districts ahead of Eid-ul-Azha are fattened allegedly by unscrupulous cattle traders ignoring the scientific formula prescribed by Livestock Department. As harmful processes to fatten cattle start several months before Eid-ul-Azha, the animals are affected with serious diseases, posing serious health hazard for consumers (Personal communication).

However, almost no attention has been paid in Bangladesh in respect of using anabolic steroid and feed additives in small scale cattle fattening. Problems, prospects and health 
hazards on the use of these substances are not well documented in Bangladesh. Keeping all these matters in view, the present study was conducted with the following objectives:

i) To investigate use of anabolic steroids and feed additives for cattle fattening in selected districts of Bangladesh;

ii) To find out the relationship among different aspects of cattle fattening and use of anabolic steroids and feed additives.

\section{METHODOLOGY}

The data were collected using a pretested interview schedule involving 150 respondents of 6 upazila (Mymensingh Sadar and Haluaghat of Mymensingh district, Pabna Sadar and Atgharia of Pabna district and Comilla Sadar and Barura of Comilla districts) in 3 districts of Bangladesh. The respondents were mainly involved in cattle fattening by using anabolic steroid and feed additives before Eid-ul-Azha (October-November, 2011).

Table 1. Distribution of the respondents

\begin{tabular}{l|c|c}
\hline \multicolumn{1}{c|}{ District } & Upazila & No. of farmers \\
\hline Mymensingh & Haluaghat & 35 \\
& Mymensingh Sadar & 15 \\
Pabna & Atgharia & 12 \\
& Pabna Sadar & 38 \\
Comilla & Barura & 30 \\
& Comilla Sadar & 20 \\
\hline
\end{tabular}

The structured interview scheduled was designed to collect information from the farmers on the uses of anabolic steroid and feed additives. The schedule was developed in a simple manner to avoid misunderstanding and to get accurate answer. Data were collected following the direct interviews and making personal visits. Before making actual interview, the objectives of the study were explained clearly to the respondents. Then the questions were asked in a very simple manner with explanation wherever necessary. Interviews were normally conducted in the market or in respondent's house during their leisure time. Excellent co operation and co-ordination was obtained from all the respondents, field extensions staffs of DLS and different companies' personnel during data collection. Data collection was started on October, 2011 and completed on November, 2011. Secondary data were collected at different times from drug pharmacy, veterinary doctor, Upazila livestock officer, BBS, journals, reports and various published articles. The interview schedule contained information related to socioeconomic status of the respondents, livestock population, management of the fattening cattle, feeds and feeding cattle, indigenous knowledge on rearing and marketing of cattle, and application of anabolic steroid and feed additives etc. It also contained the sources of information to use anabolic steroid and feed additives and also the impact of anabolic steroids and feed additives on growth rate of fattened cattle. All interview schedules were compiled, coded, 
tabulated and analyzed according to the objectives of the study. The collected data were first transferred to MS- Excel spread sheets and compiled to facilitate the needed tabulation. Tabular technique was applied for the analysis of data using simple statistical tools like average and percentages as well as Chi-square $\left(\mathrm{x}^{2}\right)$ value, spearman correlation coefficient $\left(\mathrm{r}_{\mathrm{s}}\right)$, and level of significance through SPSS Statistics 17.0 software for quantitative and qualitative data.

\section{RESULTS AND DISCUSSION}

\section{Socio-economic status of the respondents}

Table 2 shows that the majority $(72.0 \%)$ of the respondents involved in agriculture, followed by $23.3 \%$ and the rest were involved in livestock business and service, respectively. The education level of respondents were $40.0 \%$ illiterate, followed by $46.0 \%$, $10.7 \%$ and $3.3 \%$ primary level, higher secondary and graduation level of education, respectively. Majority ( $78.7 \%$ ) of the farmers start their cattle fattening business using own money, followed by $11.3 \%, 2.7 \%, 4 \%$ and $3.3 \%$ from NGO loan, bank loan, mohajon loan and loan from microcredit at high interest rate, respectively. Only $9.3 \%$ respondents had cattle fattening training and $90.7 \%$ had not received any training. Hashem et al. (1999) conducted a survey work on cattle fattening in different districts of Bangladesh and reported that about $51.2 \%$ farmers having primary education and $28 \%$ had no education. He also reported that about $22 \%$ farmers had training and $78 \%$ had no training on cattle fattening program. Ahmed et al.. (2010) found that 20.5\% farmers were trained and $79.5 \%$ were not trained. Ali et al. (2011) reported that $56 \%$ had primary education, $20 \%$ had secondary and $6 \%$ had higher secondary education and rest of them graduate and postgraduates $16 \%$ and $2 \%$, respectively and $52 \%$ farmers received training and rest of them were not trained.

\section{Factors associated with cattle fattening}

Table 3 shows that majority (92.0\%) of farmers selected beef type cattle for fattening purpose. $79.3 \%$ respondents had 2-5 number of cattle for fattening while $17.3 \%$ and $3.3 \%$ had 6-9 number and more than 10 number cattle. Among the farmers, $42.7 \%$ selected indigenous while $57.3 \%$ selected cross breed for fattening purpose. Majority (53.3\%) of the respondents start fattening before Eid-ul-Azha and the rest practiced round the year. Majority $(58.7 \%)$ of the farmers fattened cattle for 3 to 6 months, followed by $16.7 \%$ and $24.7 \%$ for 3 months or less and 6 months to 1 year, respectively. Majority $(80.7 \%)$ of them selected uncastrated male and rest of them fattened castrated male. About $66.0 \%$ cattle used for fattening age was 2 years or below and $34.0 \%$ was above 2 years. Among the respondents $70.6 \%$ used anabolic steroid as a growth hormone and rest of them did not use any kinds of growth hormone. Most (95.3\%) of the farmers used feed additives for cattle fattening while only $4.7 \%$ did not use feed additives. Hossain (1986) and Hossain et al. (1996) reported that most farmers fattened their cattle for the duration of 4-5 months and 5-7 months, respectively. 
Table 2. Distribution of respondents according to their socio-economic status ( $\mathrm{n}=150)$

\begin{tabular}{|c|c|c|c|}
\hline Parameters & Categories & No. of farmers & $\%$ of farmers \\
\hline \multirow[t]{3}{*}{ Main Occupation } & Agriculture & 108 & 72 \\
\hline & Livestock Business & 35 & 23 \\
\hline & Others & 7 & 4 \\
\hline \multirow[t]{4}{*}{ Level of Education } & Illiterate & 60 & 40 \\
\hline & Primary & 69 & 46 \\
\hline & Higher secondary & 16 & 10 \\
\hline & Above higher secondary & 5 & 3 \\
\hline \multirow[t]{3}{*}{ Family Members } & $2-4$ & 55 & 36 \\
\hline & $5-7$ & 76 & 50 \\
\hline & $8-10$ & 19 & 12 \\
\hline \multirow[t]{4}{*}{ Annual Income (BDT) } & $20000-30000$ & 71 & 47 \\
\hline & $30001-40000$ & 39 & 26 \\
\hline & $40001-50000$ & 31 & 20 \\
\hline & More than 50000 & 9 & 6 \\
\hline \multirow[t]{5}{*}{ Sources of money } & Own & 118 & 78 \\
\hline & Bank loan & 4 & 2 \\
\hline & NGO loan & 17 & 11 \\
\hline & Mohajon & 6 & 4 \\
\hline & Own + NGO loan & 5 & 3 \\
\hline \multirow{2}{*}{$\begin{array}{l}\text { Training on cattle } \\
\text { fattening }\end{array}$} & Have & 14 & 9 \\
\hline & Have not & 136 & 90 \\
\hline
\end{tabular}

\section{Use of feed additives and anabolic steroids}

Table 4 revealed that most of the farmers used anabolic steroid and feed additives as a growth promoter for cattle fattening and they prefer in powder form. About 33.33\% respondents used Avit-G, 27.54\% Amovit-G and the rest used Radivit-DB, Hyvit-DB, Megavit-DB, Vitamin-DB, Curenal and Complete-DB. About $20.37 \%$ respondents also prefer Catasol, 18.51\% Tocol, 16.66\% Asol and rest of them used Catafos, Hematophen, Buphos-Vet, Phosvet, Hematopen, Dexadet, Tredexanol, Oradexon and Decason as fattening agent in the form of injection. About $44.44 \%, 25.92 \%$ and the rest of the farmers used Anora, Roxivet, and Anorexon, Pednivet, and Biolect Bolus, respectively in the form of tablet as fattening agent. This result differed from the findings of Ali et al..(2011) who reported that $8 \%$ farmers used Pednivet and $78 \%$ used vitamin mineral premix as a feed additives. This inconsistent might be due to cultural and / or geographical variation. Feed conversion efficiency was improved in bull calves by using Metafos (Minerals derivatives) and Biomix-DB (Vitamin-mineral premix) reported by. 
Table 3. Distribution of the factors associated with cattle fattening $(n=150)$

\begin{tabular}{|c|c|c|c|}
\hline Parameters & Categories & No. of farmers & $\%$ of farmers \\
\hline \multirow[t]{3}{*}{ Farm type } & Beef type & 138 & 92 \\
\hline & Dairy type & 4 & 2 \\
\hline & Beef + Dairy & 8 & 5 \\
\hline \multirow[t]{3}{*}{ No. of cattle fattening } & $2-5$ & 119 & 79 \\
\hline & $6-9$ & 26 & 17 \\
\hline & $>10$ & 5 & 3 \\
\hline \multirow[t]{2}{*}{ Breed of cattle } & Indigenous & 64 & 42 \\
\hline & Cross & 86 & 57 \\
\hline \multirow[t]{2}{*}{ Pattern of the program } & Just before eid-ul-azha & 80 & 53 \\
\hline & Round the year & 70 & 46 \\
\hline \multirow[t]{3}{*}{ Fattening period } & 3 months or less & 25 & 16 \\
\hline & 3 to 6 months & 88 & 58 \\
\hline & 6 months to 1 year & 37 & 24 \\
\hline \multirow[t]{2}{*}{ Sex of animal } & Castrated male & 29 & 19 \\
\hline & Uncastrated male & 121 & 80 \\
\hline \multirow[t]{2}{*}{ Starting age } & 2 yrs or below & 99 & 66 \\
\hline & Above 2 yrs & 51 & 34 \\
\hline \multirow[t]{2}{*}{ Finishing age } & 3 yrs or below & 119 & 79 \\
\hline & Above 3 yrs & 31 & 20 \\
\hline \multirow[t]{2}{*}{ Anabolic steroid } & Practiced & 106 & 70 \\
\hline & Non-practiced & 44 & 29 \\
\hline \multirow[t]{2}{*}{ Feed additives } & Practiced & 143 & 95 \\
\hline & Non-practiced & 7 & 4 \\
\hline
\end{tabular}

Table 5 revealed that Most $(86 \%)$ of the respondents used anabolic steroid in Pabna districts and has a significant difference $(\mathrm{P}<0.01)$ from other two districts. The result demonstrated that respondents of low income used more anabolic steroid. About 30 to $60 \%$ of the farmers' income came from cattle fattening business. About $58 \%$ respondents used anabolic steroid for the period of 3 to 6 months cattle fattening $(\mathrm{P}<0.001)$. Significant $(\mathrm{P}<0.01)$ association was observed on the use of anabolic steroids with different districts, annual income, source of money, number of cattle fattened, breeds of cattle, fattening period, starting and finishing age. The $x^{2}$-value of annual income was 14.97 indicating that increase of annual income was associated with decrease of anabolic steroids and 2-5 heads of cattle are highly fattened using growth promoters $(\mathrm{P}<0.05)$. Most of the farmers used their own capital for using anabolic steroid and feed additives $(\mathrm{P}<0.001)$. The $\mathrm{r}_{\mathrm{s}}$ value of annual income, source of money, number of cattle fattening starting and finishing age was positively correlated with practice of anabolic steroid. The $r_{s}$ value of fattening periods is - 
0.85 which indicates that the use of anabolic steroids was increased with the decreased fattening period $(\mathrm{P}<0.01)$. While working with the farmers in rural areas of Bangladesh, Hossain (1986) and Hossain et al. (1996) reported cattle fattening periods of 4-5 months and 5.7 months, respectively.

Table 4. Distribution of feed additives and anabolic steroids $(n=150)$

\begin{tabular}{|c|c|c|c|c|}
\hline \multicolumn{3}{|c|}{ Feed additives } & \multicolumn{2}{|c|}{ Anabolic steroids } \\
\hline Powder & Injection & Tablet & Injection & Tablet \\
\hline $\begin{array}{l}\text { Avit-G (Vitamin, } \\
\text { Mineral premix) }\end{array}$ & $\begin{array}{l}\text { Catasol } \\
\text { (Butaphosphan, Vit } \\
\mathrm{B}_{12} \text { ) }\end{array}$ & $\begin{array}{l}\text { Anora (Iron, } \\
\text { Vitamin) }\end{array}$ & $\begin{array}{c}\text { Oradexon } \\
\text { (Glucocorticoid } \\
\text { steroid) }\end{array}$ & $\begin{array}{l}\text { Pednivet } \\
\text { (Steroids) }\end{array}$ \\
\hline $\begin{array}{l}\text { Amovit-G } \\
\text { (Vitamin, Mineral } \\
\text { premix) }\end{array}$ & $\begin{array}{l}\text { Tocol (Vitamin E, } \\
\text { Vit } \mathrm{B}_{12} \text { ) }\end{array}$ & $\begin{array}{c}\text { Roxivet (Vit B } \mathrm{B}_{12} \text {, } \\
\text { iron) }\end{array}$ & $\begin{array}{c}\text { Decason } \\
\text { (Glucocorticoid } \\
\text { steroid) }\end{array}$ & \\
\hline $\begin{array}{l}\text { Hyvit-DB } \\
(\text { VitaminB, D) }\end{array}$ & Asol (Vit B12) & $\begin{array}{l}\text { Anorexon (Iron, Vit } \\
\mathrm{B}_{1}, \text { Vit } \mathrm{B}_{12} \text { ) }\end{array}$ & $\begin{array}{c}\text { Dexadet (Synthetic } \\
\text { Steroid) }\end{array}$ & \\
\hline $\begin{array}{l}\text { Radivit-DB } \\
\text { (Vitamin B, D) }\end{array}$ & $\begin{array}{l}\text { Catafos } \\
\text { (Butaphosphan, Vit } \\
\mathrm{B}_{12} \text { ) }\end{array}$ & $\begin{array}{l}\text { Biolect Bolus } \\
\text { (Enzyme) }\end{array}$ & $\begin{array}{c}\text { Tredexanol (Synthetic } \\
\text { Steroid) }\end{array}$ & \\
\hline $\begin{array}{l}\text { DB-Vitamin } \\
\text { (Vitamin A, D) }\end{array}$ & $\begin{array}{l}\text { Buphos-Vet } \\
\text { (Butaphosphan,Vit } \\
\mathrm{B}_{12} \text { ) }\end{array}$ & & & \\
\hline $\begin{array}{l}\text { Megavit-DB } \\
\text { (Methionine, } \\
\text { Lysine) }\end{array}$ & $\begin{array}{l}\text { Phosvet } \\
\text { (Toldimphos, Vit } \\
\mathrm{B}_{12} \text { ) }\end{array}$ & & & \\
\hline $\begin{array}{l}\text { Complete-DB } \\
\text { (Vitamin, } \\
\text { Minerals) }\end{array}$ & $\begin{array}{l}\text { Hematopen (Vit } \\
\left.\mathrm{B}_{12}\right)\end{array}$ & & & \\
\hline $\begin{array}{l}\text { Curenal (Ferus } \\
\text { Sulphate, Vit } B_{1} \text { ) }\end{array}$ & & & & \\
\hline
\end{tabular}

Table 6 revealed that feed additives was used by all of respondents in Pabna districts and has a significant $(\mathrm{P}<0.01)$ difference from those of other two districts. The result demonstrated that respondents of low annual income used more feed additives and in that case 30 to $60 \%$ of their income came from cattle fattening business. About $78 \%$ respondents used feed additives which was significantly $(\mathrm{P}<0.01)$ associated with own sources of money and they used mainly for 3 to 6 months $(\mathrm{P}<0.01)$ period for fattening. On the basis of $x^{2}$-value, significant $(P<0.01)$ association was observed on the use of feed additives with different districts, source of money and fattening period.

Table 7 shows that the $r_{s}$ value of source of money is -0.265 indicates that with the increase of annual income decreases the uses of feed additives. Impact on growth also negatively correlated with feed additives $\left(r_{s}=-0.299\right)$. Beeson (1959) stated that there is no doubt that feed additives have made a great contribution to improve the performance and general health of livestock. 
Table 5. Use of anabolic steroids $(n=150)$

\begin{tabular}{|c|c|c|c|c|c|c|}
\hline Parameter & Categories & Practiced & Not-practiced & Total & $\mathrm{X}^{2}$-value & Level of sig. \\
\hline \multirow[t]{3}{*}{ District } & Mymensingh & 29 & 21 & 50 & 11.143 & $* *$ \\
\hline & Comilla & 36 & 14 & 50 & & $(\mathrm{P}<0.01)$ \\
\hline & Pabna & 43 & 7 & 50 & & \\
\hline \multirow[t]{3}{*}{ Main Occupation } & Agriculture & 101 & 7 & 108 & 0.710 & NS \\
\hline & Liv. Business & 32 & 3 & 35 & & \\
\hline & Others & 7 & 0 & 7 & & \\
\hline \multirow{4}{*}{$\begin{array}{l}\text { Annual Income } \\
\text { (BDT }\end{array}$} & $20000-30000$ & 69 & 2 & 71 & 14.970 & ** \\
\hline & $31000-40000$ & 38 & 1 & 39 & & $(\mathrm{P}<0.01)$ \\
\hline & $41000-50000$ & 27 & 4 & 31 & & \\
\hline & Above 50000 & 6 & 3 & 9 & & \\
\hline \multirow[t]{5}{*}{ Source of money } & Own & 115 & 3 & 118 & 36.835 & $* *$ \\
\hline & Bank Loan & 4 & 0 & 4 & & $(\mathrm{P}<0.01)$ \\
\hline & NGO Loan & 10 & 7 & 17 & & \\
\hline & Loan Mohajn & 6 & 0 & 6 & & \\
\hline & Own+NGO & 5 & 0 & 5 & & \\
\hline \multirow{3}{*}{$\begin{array}{l}\% \text { of income from } \\
\text { fattening business }\end{array}$} & $<30 \%$ & 46 & 1 & 47 & 2.862 & NS \\
\hline & 30 to $60 \%$ & 81 & 7 & 88 & & \\
\hline & $>60 \%$ & 13 & 2 & 15 & & \\
\hline \multirow[t]{3}{*}{ Farm type } & Beef & 129 & 9 & 138 & 2.737 & NS \\
\hline & Dairy & 3 & 1 & 4 & & \\
\hline & Beef \& Dairy & 8 & 0 & 8 & & \\
\hline \multirow{3}{*}{$\begin{array}{l}\text { No. of cattle } \\
\text { fattening }\end{array}$} & $2-5$ & 114 & 5 & 119 & 5.766 & * \\
\hline & $6-9$ & 22 & 4 & 26 & & $(\mathrm{P}<0.05)$ \\
\hline & $>10$ & 4 & 1 & 5 & & \\
\hline \multirow[t]{2}{*}{ Breeds of cattle } & Indigenous & 57 & 7 & 64 & 3.272 & * \\
\hline & Cross & 83 & 3 & 86 & & $(\mathrm{P}<0.05)$ \\
\hline \multirow{2}{*}{$\begin{array}{l}\text { Pattern of } \\
\text { fattening }\end{array}$} & Eid-ul-Azha & 77 & 3 & 80 & 2.344 & NS \\
\hline & Round the year & 63 & 7 & 70 & & \\
\hline \multirow[t]{3}{*}{ Fattening Period } & $3 \mathrm{~m}$ or less & 19 & 6 & 25 & 15.351 & $* *$ \\
\hline & 3 to $6 \mathrm{~m}$ & 84 & 4 & 88 & & $(\mathrm{P}<0.01)$ \\
\hline & $6 \mathrm{~m}$ to $1 \mathrm{yrs}$ & 37 & 0 & 37 & & \\
\hline \multirow[t]{2}{*}{ Starting age } & 2 yrs or below & 96 & 3 & 99 & 6.188 & * \\
\hline & $>2$ yrs & 44 & 7 & 51 & & $(\mathrm{P}<0.05)$ \\
\hline \multirow[t]{2}{*}{ Finishing age } & $3 y r s$ or below & 117 & 2 & 119 & 23.006 & $* * *$ \\
\hline & $>3 y r s$ & 23 & 8 & 31 & & $(\mathrm{P}<0.01)$ \\
\hline \multirow{3}{*}{$\begin{array}{l}\text { Name of anabolic } \\
\text { steroid }\end{array}$} & Powder & 56 & 6 & 62 & 4.238 & NS \\
\hline & Injection & 60 & 1 & 61 & & \\
\hline & Tablet & 24 & 3 & 27 & & \\
\hline \multirow{2}{*}{$\begin{array}{l}\text { Source of anabolic } \\
\text { steroid }\end{array}$} & Pharmacy & 115 & 8 & 123 & 0.29 & NS \\
\hline & NGO worker & 25 & 2 & 27 & & \\
\hline
\end{tabular}

NS, Non-significant $(\mathrm{P}>0.05) ;{ }^{*}, \mathrm{P}<0.05$ and ${ }^{* *}, \mathrm{P}<0.01$ 
Different feed additives and sources $(n=150)$

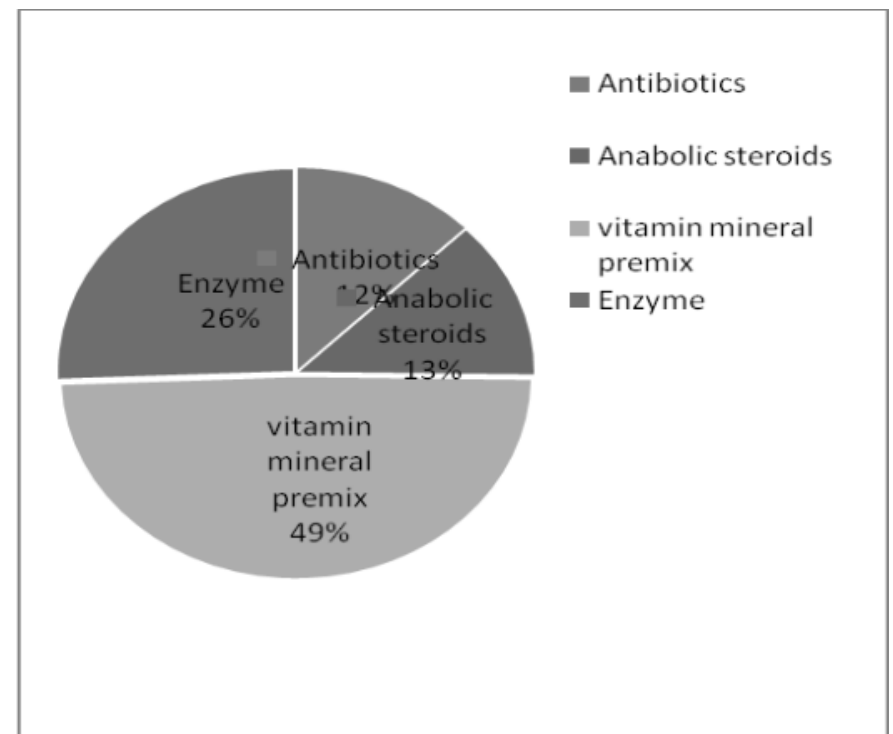

Fig. 1. Different feed additives

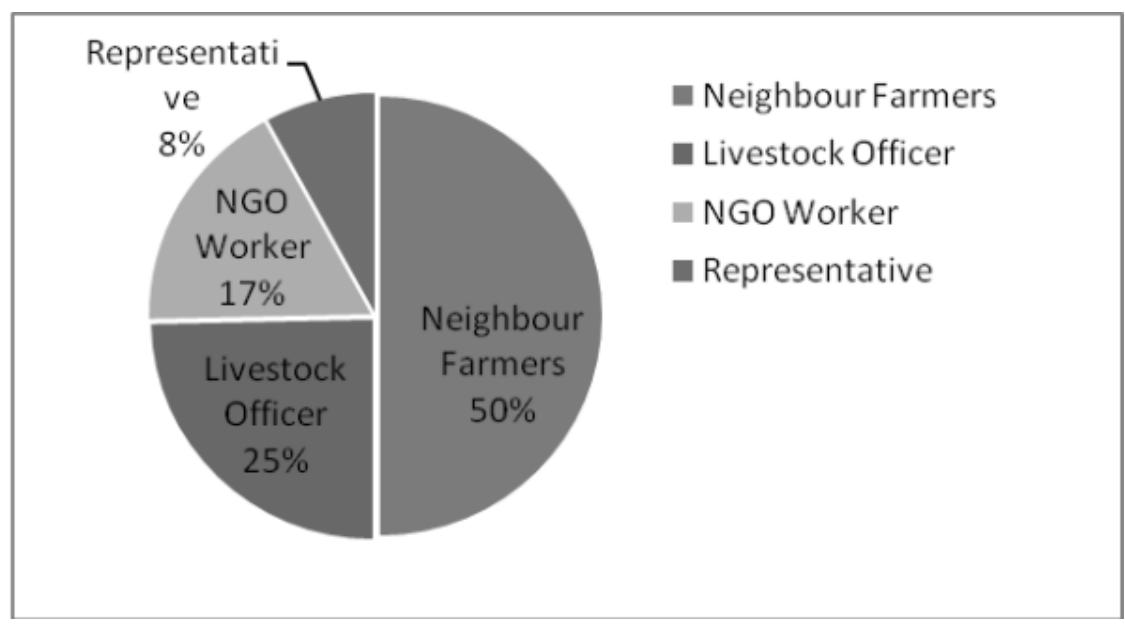

Fig. 2. Sources of different feed additives

Based on the sources of feed additives, the pie chart shows athat bout $49 \%$ respondents used vitamin mineral premix, $26 \%$ enzyme, $12 \%$ antibiotics and $13 \%$ anabolic steroids for cattle fattening. The sources of feed additives vary farmers to farmers. In pie chart 2 shows that most $(50 \%)$ of the farmers knew about the use of feed additives from neighbour farmers, $25 \%$ from livestock officer, $17 \%$ from NGO workers and the rest $8 \%$ from veterinary representative. This result differed from the report of Ali et al. (2011) who found that $90 \%$ farmers used feed additives, $8 \%$ used vitamin-minerals premix and only $4 \%$ used anabolic steroids. 
Table 6. Use of feed additives $(n=150)$

\begin{tabular}{|c|c|c|c|c|c|c|}
\hline Parameter & Categories & Practiced & $\begin{array}{c}\text { Not- } \\
\text { practiced }\end{array}$ & Total & $\begin{array}{c}X^{2}- \\
\text { value }\end{array}$ & Level of sig. \\
\hline \multirow[t]{3}{*}{ District } & Mymensingh & 45 & 5 & 50 & 0.000 & $*(\mathrm{P}<0.05)$ \\
\hline & Comilla & 47 & 2 & 50 & & \\
\hline & Pabna & 50 & 0 & 50 & & \\
\hline \multirow[t]{3}{*}{ Main Occupation } & Agriculture & 106 & 2 & 108 & 0.286 & NS \\
\hline & Liv. Business & 34 & 1 & 35 & & \\
\hline & Others & 7 & 0 & 7 & & \\
\hline \multirow{4}{*}{$\begin{array}{l}\text { Annual } \\
\text { Income(BDT) }\end{array}$} & $20000-30000$ & 70 & 1 & 71 & 4.241 & NS \\
\hline & $31000-40000$ & 39 & 0 & 39 & & \\
\hline & $41000-50000$ & 29 & 2 & 31 & & \\
\hline & above 50000 & 9 & 0 & 9 & & \\
\hline \multirow[t]{5}{*}{ Source of money } & Own & 117 & 1 & 118 & 16.07 & $* *$ \\
\hline & Bank Loan & 4 & 0 & 4 & & $(\mathrm{P}<0.01)$ \\
\hline & NGO Loan & 17 & 0 & 17 & & \\
\hline & Loan Mohajn & 5 & 1 & 6 & & \\
\hline & Own+NGO & & & & & \\
\hline \multirow{3}{*}{$\begin{array}{l}\% \text { of family income } \\
\text { from fattening } \\
\text { business }\end{array}$} & $<30 \%$ & 47 & 0 & 47 & 2.659 & NS \\
\hline & 30 to $60 \%$ & 86 & 2 & 88 & & \\
\hline & $>60 \%$ & 14 & 1 & 15 & & \\
\hline \multirow[t]{3}{*}{ Farm type } & Beef & 135 & 3 & 138 & 0.266 & NS \\
\hline & Dairy & 4 & 0 & 4 & & \\
\hline & Beef \&Dairy & 8 & 0 & 8 & & \\
\hline \multirow{3}{*}{$\begin{array}{l}\text { No. of cattle } \\
\text { fattening }\end{array}$} & $2-5$ & 117 & 2 & 119 & 0.616 & NS \\
\hline & $6-9$ & 25 & 1 & 26 & & \\
\hline & $>10$ & 5 & 0 & 5 & & \\
\hline \multirow[t]{2}{*}{ Breeds of cattle } & Indigenous & 63 & 1 & 64 & 0.109 & NS \\
\hline & Cross & 84 & 2 & 86 & & \\
\hline \multirow[t]{2}{*}{ Pattern of fattening } & Eid-ul-Azha & 78 & 2 & 80 & 0.210 & NS \\
\hline & Round the year & 69 & 1 & 70 & & \\
\hline \multirow[t]{3}{*}{ Fattening Period } & $3 \mathrm{~m}$ or less & 24 & 1 & 25 & 0.038 & $* *$ \\
\hline & 3 to $6 \mathrm{~m}$ & 87 & 1 & 88 & & $(\mathrm{P}<0.01)$ \\
\hline & $6 \mathrm{~m}$ to $1 \mathrm{yrs}$ & 36 & 1 & 37 & & \\
\hline \multirow[t]{2}{*}{ Sex of animal } & Castrated male & 28 & 1 & 29 & 0.358 & NS \\
\hline & Uncastrated male & 119 & 2 & 121 & & \\
\hline
\end{tabular}

NS, Non-significant $(\mathrm{P}>0.05) ;{ }^{*}, \mathrm{P}<0.05$ and ${ }^{* *}, \mathrm{P}<0.01$ 
Table 7. Estimated values of $r$ of feed additives $(n=150)$

\begin{tabular}{lcc}
\hline \multicolumn{1}{c|}{ Parameter } & Spearman correlation coefficient $\left(\mathrm{r}_{\mathrm{s}}\right)$ & Level of significance \\
\hline Education level & -0.042 & $\mathrm{NS}$ \\
Annual income & -0.072 & $\mathrm{NS}$ \\
Source of money & -0.265 & $* *$ \\
Breeds of cattle & -0.027 & $\mathrm{NS}$ \\
Fattening period & 0.018 & $\mathrm{NS}$ \\
Impact on growth & -0.299 & $*$ \\
Antibiotics & 0.073 & $\mathrm{NS}$ \\
Steroids & -0.154 & $\mathrm{NS}$ \\
Vit-mineral premix & 0.057 & $\mathrm{NS}$ \\
Enzymes & -0.067 & $\mathrm{NS}$ \\
\hline
\end{tabular}

rs, Spearman correlation coefficient; NS, Non-significant $(\mathrm{P}>0.05) ;{ }^{*}, \mathrm{P}<0.05$ and ${ }^{* *}, \mathrm{P}<0.01$

\section{Problems and suggestions to improve cattle fattening}

Table 8 shows that the most important problem faced by the respondents $(34 \%)$ was the high price of concentrate feed. followed by lack of knowledge $(27.33 \%)$ for the selection of appropriate breed, capital problem (20\%) and lack of knowledge about feed additives and anabolic steroids (8.7\%). This result differed from Ali M. A. et al. (2011) who reported that about $74 \%$ of the respondents had no problem in using the anabolic steroids and feed additives and the rest $26 \%$ did not give any answer to this question. This result was also in agreement with the findings of Rahman et al., (2001) where 70\% respondents reported high price of concentrate feeds. Hashem et al., (1999) reported that lack of training, credit facilities, feed price hiking, disorganized marketing system were also problems related to cattle fattening in Bangladesh.

Table 8. Problems and possible suggestions to improve cattle fattening $(n=150)$

\begin{tabular}{lc|c}
\hline \multicolumn{1}{c|}{ Problems } & No. of farmers & \% of farmers \\
\hline High price of concentrates & 51 & 34 \\
Lack of knowledge for selection of appropriate breed & 41 & 27 \\
Capital problem & 30 & 20 \\
Disease(s) problem & 15 & 10 \\
Lack of knowledge using feed additives and anabolic steroids & 13 & 8 \\
Suggestions & & \\
Selection of animal on the basis of breed, color, age, skin, sex & 54 & 36 \\
and eye & & \\
Good feeding and management & 38 & 25 \\
Deworming for regular basis & 28 & 18 \\
Reduced cost of concentrates & 20 & 13 \\
Availability of training facilities on cattle fattening & 10 & 6 \\
\hline
\end{tabular}


Table 8 also shows that $36.0 \%$ respondents suggested that selection of breed is the first key to cattle fattening, followed good feeding and management $(25.3 \%)$, dewarming $(18.7 \%)$, reduction of concentrate feed cost $(13.3 \%)$ and availability of training facilities for cattle fattening $(6.7 \%)$.

\section{CONCLUSION}

It can be concluded that majority of the respondents used feed additives in the form of powder as a fattening agent. The result also demonstrated that about most of low income group of respondents used anabolic steroids for fattening purpose. It also has been stated that decrease of anabolic steroid use is associated with increase of annual income of the respondents. Studies to explore more information related to socio-economic condition of the farmers who are involved in fattening business are necessary.

\section{ACKNOWLEDGEMENT}

The authors wish to acknowledge and thanks to UGC for financial support.

\section{RFERENCES}

Ali, M., A., Shahzaman, Khan, 2011. Study on growth promoters used for cattle fattening in Bangladesh. M. S. Thesis. Department of Animal Nutrition, BAU, Mymensingh, Bangladesh.

BBS (Bangladesh Bureau of Statistics). 2009. Statistical Pocket Book of Bangladesh. Statistics Division, Ministry of planning, Government of the Peoples Republic of Bangladesh.

BBS (Bangladesh Bureau of Statistics). 2010. Statistical Yearbook of Bangladesh. Statistics Division, Ministry of planning, Government of the Peoples Republic of Bangladesh.

Beeson, 1959. A Critique of Food Additives, Presented at the National Feed Ingredients Association Convention, October 1-2, 1959, Chicago, Illinois.

BER, 2007. Bangladesh Economic Review. Ministry of planning, Government of the Peoples Republic of Bangladesh.

DLS (Directorate of livestock Services), 2009. General information related to Livestock. Monthly Fisheries and Livestock Bulletin, published by Fisheries and Livestock Information Office, Khamarbari, Farmgate, Dhaka, Bangladesh.

FAO, 2010. Selected indicators of Food and Agriculture Development in Asia- pacific region, 1993-2003. Food and Agriculture Organization of the United Nations. Bangkok, Thailand. pp. 119-121.

Hashem, M. A., Moniruzzaman, M., Akhter, S. and Hossain, M. M. 1999. Cattle fattening by rural farmers in different districts of Bangladesh. Bang. J. Anim. Sci., 28(1-2): 81-88. 
Hoffman, J. R., Faigenbaum, A. D., Ratamess, N. A., Ross, R., Kang J. and Tenenbaum, G. 2008. Nutritional supplementation and anabolic steroid use in adolescents. Medicine and Science in Sports and Exercise. Vol. 40 (1): pp15-24.

Hossain, K. M., Nahar, T. N., Talukder, A. I. and Kibria, S. S. 1996. Beef fattening by rural women. In the proceeding of a national workshop on case studies "Success stories of women in Agriculture." 27-28 August, 1995, BARC, Dhaka, Bangladesh.

Hossain, M. M. 1986. Study of cattle fattening program by landless and youth. Bang. J. Anim. Sci., 15(1-2): 85-88.

Hossain, M. S., Hossain, M. M., Hashem, M. A. and Ali, R. N. 1996a. Transfer of feeding technology to promote cattle production of village level. Bang. J. Anim. Sci., 25(1-2): 51-56.

Rahman, S. M. E., Hossain, M. M., Majumder, S. and Samad, M. A. 2001. Cattle fattening with Urea Molasses Straw and its effect on intake, growth and digestibility. Bang. J. Anim. Sci., 30(1-2): 99-105.

Scarth, J., Akre, C., van Ginkel, L., Le Bizec, B., De Brabander, H., Korth, W., Points, J., Teale, P., Kay, J. 2009. Presence and metabolism of endogenous androgenic-anabolic steroid hormones in meat-producing animals: a review. Food Addit Contam Part a Chem Anal Control Expo Risk Assess. 26(5): 640-71.

Skunmun, P., Chantalakhana, C., Pungchai, R., Poondusit, T. and Prucsasri, P. 2002. Comparative Feeding of Nale Dairy, Beef Cattle and Swamp Buffalo. 1. Economics of Beef Production. Asian-Aust. J. Anim. Sci. 15(6): 878-883.

Smith, J. L., Wison, L. L. and Swanson, D. L. 2007, Inplant sequence effects in intact male Holstein veal calves; live and slaughter traits. J. Anim. Sci., 77(12): 3125-3132. 